\title{
Endogenous and food-derived polyamines: determination by electrochemical sensing
}

\author{
Davide Baratella ${ }^{1}$ Emanuela Bonaiuto ${ }^{1}$ - Massimiliano Magro ${ }^{1,2}$. Jessica de Almeida Roger ${ }^{1}$ ' Yuta Kanamori ${ }^{3,4}$. \\ Giuseppina Pace Pereira Lima ${ }^{5} \cdot$ Enzo Agostinelli, $^{3,4} \cdot$ Fabio Vianello $^{1}$ (1)
}

Received: 8 March 2018 / Accepted: 10 July 2018 / Published online: 21 July 2018

○) Springer-Verlag GmbH Austria, part of Springer Nature 2018

\begin{abstract}
Polyamines (PAs) are involved in a variety of fundamental physio-pathologic processes. The concentration of these polycations in organs and tissues depends on their endogenous production and oxidation rates, and on their intake from foods. Besides being largely accepted as markers for the progress of several pathologies, PAs may exert themselves different effects on humans, ranging from being positive to be drastically detrimental depending on the organism conditions. Thus, if the determination of polyamines content in tissue samples is of great importance as they could be indicators of several diseases, their quantification in food is fundamental for modulating the diet to respond to a specific human health status. Thus, the determination of PA content in food is increasingly urgent. Standard analytical methods for polyamine quantification are mainly based on chromatography, where high-performance liquid chromatography and gas chromatography are the most often used, involving pre-column or post-column derivatization techniques. Driven by the growing need for rapid in situ analyses, electrochemical biosensors, comprising various combinations of different enzymes or nanomaterials for the selective bio-recognition and detection, are emerging as competitors of standard detection systems. The present review is aimed at providing an up-to-date overview on the recent progresses in the development of sensors and biosensors for the detection of polyamines in human tissues and food samples. Basic principles of different electrochemical (bio)sensor formats are reported and the applications in human tissues and in foods was evidenced.
\end{abstract}

Keywords Polyamines $\cdot$ Detection $\cdot$ Electrochemistry $\cdot$ Biosensor $\cdot$ Analytical chemistry $\cdot$ Amine oxidases

PubChem CID Putrescine (1045) · Cadaverine (273) · Spermine (1103) · Spermidine (1102) · Agmatine (199)

Handling Editor: J. D. Wade

Davide Baratella and Emanuela Bonaiuto contributed equally to this work.

Fabio Vianello

fabio.vianello@unipd.it

1 Department of Comparative Biomedicine and Food Science, University of Padua, Legnaro, PD, Italy

2 Regional Centre of Advanced Technologies and Materials, Palacky University, Olomouc, Czech Republic

3 Department of Biochemical Sciences "A. Rossi Fanelli”, University of Rome "La Sapienza", Rome, Italy

4 CNR-National Research Council of Italy, Institute of Molecular Biology and Pathology, IBPM of CNR, Rome, Italy

5 Department of Chemistry and Biochemistry, Universidade Estadual Paulista (UNESP), Botucatu, São Paulo, Brazil

$\begin{array}{ll}\text { Abbreviations } \\ \text { AUH } & \text { Agmatinase } \\ \text { CA } & \text { Chronoamperometry } \\ \text { CP } & \text { Carbon paste } \\ \text { CV } & \text { Cyclic voltammetry } \\ \text { DPV } & \text { Differential pulse voltammetry } \\ \text { FIA } & \text { Flow injection analysis } \\ \text { GC } & \text { Glassy carbon electrode } \\ \text { SPCE } & \text { Screen printed carbon electrodes } \\ \text { SPE } & \text { Screen printed electrode } \\ \text { SWV } & \text { Square wave voltammetry } \\ \text { TTF } & \text { Tetrathiafulvalene }\end{array}$

Abbreviations

AUH Agmatinase

CA Chronoamperometry

CP Carbon paste

CV Cyclic voltammetry

$\begin{array}{ll}\text { DPV } & \text { Differential pulse voltam } \\ \text { FIA } & \text { Flow injection analysi }\end{array}$

GC Glassy carbon electrode

SPCE Screen printed carbon electrodes

SWV Square wave voltammetry

TTF Tetrathiafulvalene 


\section{Introduction}

Polyamines (PAs) are an essential group of metabolites found in all living organisms and involved in many physiological functions, including promoters of plant life and with differential roles in human health and disease, as recently excellently reviewed (Handa et al. 2018). The research history of these compounds begun in 1674 when van Leeuwenhoek observed spermine crystals in semen samples with a rudimental microscope (Bachrach 2010). In general, the "aliphatic polyamine" term is used to designate five compounds, specifically: putrescine (PUT) or butane-1,4-diamine; spermidine (SPD) or $N^{\prime}$ (3-aminopropyl)butane-1,4-diamine; spermine, (SPM) or $N, N^{\prime}$-bis(3-aminopropyl)butane-1,4-diamine; cadaverine (CAD) or pentane-1,5-diamine; agmatine (AGM) or 2-(4-aminobutyl)guanidine. The biosynthesis of PAs was well described in Michael (2016). They are derived from the metabolism of amino acids (Bae et al. 2018; Miller-Fleming et al. 2015): PUT, SPM, SPD and CAD are derived from ornithine, after an initial decarboxylation (Seiler et al. 1996), while AGM was identified as a polyamine derived from arginine (Joshi et al. 2007). Chemically, PAs are water-soluble low molecular weight aliphatic amines, with $\mathrm{pKa}$ values at about $\mathrm{pH}=10$, and fully protonated at neutral pH (Seiler et al. 1996). They are, therefore, polycations under physiological conditions. These physico-chemical features are responsible of their biological effects through the strong electrostatic interactions with different polyanionic macromolecules, such as DNA and RNA (Agostinelli 2016). These bound PAs are in equilibrium with a free PA pool (around $7-10 \%$ of the total cell content).

The body pool of PAs is maintained by three sources, endogenous biosynthesis, intestinal microorganisms production and exogenous supply through the diet. The normal adult diet provides the largest amount of PAs in humans (Jeevanandam and Petersen 2001). Besides endogenous polyamines, their diet intake deserves a particular attention since they can exert positive or negative effects on human health. Oral polyamine administration appeared to inhibit the progression of age-associated pathologies (Soda et al. 2009) and, among PAs, spermidine was proposed as promising longevity drug (Kaeberlein 2009). Spermidine seemed to significantly stimulate human hair growth (Ramot et al. 2011). On the other hand, a polyamine deficient diet as nutritional therapy could be part of an effective strategy for pre-emptive analgesia, as well as for reducing the transition from acute to chronic pain (Rivat et al. 2008). Moreover, a reduced polyamine dietary intake is well tolerated and beneficial for the quality of life and pain control in cancer patients (Cipolla et al. 2003).
Increased levels of polyamines enhance the capability of cancer cells to invade new tissues (Damiani and Wallace 2018), while affecting immune cells functions (Soda 2011).

The present review responds to the need of fast and costeffective detection systems for widespreading the monitoring of PAs over the multitude of available real samples.

Electrochemical sensors arouse interest for their convenient instrumental set-up, short analysis time, low cost and experimental simplicity. They do not require cumbersome sample clean-up, derivatization procedures and they can be used for in situ analysis. Electrochemical sensors meet the desired properties of a chemical sensor, such as high sensitivity, wide dynamic range, low limit of detection, short response time, long lifetime, low cost, and easy handling (Hierlemann and Gutierrez-Osuna 2008).

The first part of the present review describes different examples of sensors applied for the determination of polyamines in food samples, while the second part deals with sensors applied for polyamine detection in samples of human origin. Sensors that do not report on an application to real samples were intentionally excluded from this review.

\section{Methods for the determination of polyamines}

Analytical methods for the determination of PAs are mainly based on chromatographic separations using high-performance liquid chromatography (HPLC) or gas chromatography (GC) followed by the detection by mass spectrometry (MS) (Aflaki et al. 2017; Chen et al. 2010; Herrero et al. 2016; Pinto et al. 2016; Self et al. 2011). Alternatively, upon pre- or post-column derivatization, UV and fluorescence spectroscopy detectors are commonly integrated with chromatographic methods as well (Latorre-Moratalla et al. 2009; Nishikawa et al. 2012). Actually, a chemical derivatization is mandatory to allow the sensitive determination of PAs by spectroscopic techniques, as their molecular structure lacks of moieties with optical or fluorescent properties (Al-Hadithi and Saad 2011). In addition, thin layer chromatography (Lapa-Guimarães and Pickova 2004), ion mobility spectrometry (Parchami et al. 2017), NMR (Shumilina et al. 2016) and colorimetric methods (Morsy et al. 2016), were also proposed.

Sensor and biosensors represent competitive options to these conventional analytical methods.

For simplicity, a sensor is constituted of three main components: a receptor, a transducer and an electronic component. The receptor recognizes the analytes in a complex matrix leading to a chemical recognition event. The transducer converts the chemical recognition event into a detectable electric signal for the following instrumental 
processes. The electronic component filtrates, amplifies and operates the electric signal to optimize the final readout.

The sensor transduction systems can operate according to different physical principles. Sensing devices based on calorimetric (Yakovleva et al. 2013), gravimetric (Pohanka 2018), optical (Borisov and Wolfbeis 2008), and electrochemical transducers have been reported. Some of them aimed at the determination of PAs showed excellent analytical performances (Kuo et al. 2018).

By definition, an electrochemical sensor, is based on the presence of an electrochemical transducer, transforming the analyte-sensor interaction in an electrochemical signal (Hulanicki et al. 1991; Thévenot et al. 2001) (Fig. 1).

Three different electrochemical transducers can be found in literature: amperometric, potentiometric, and impedimetric systems. Amperometric transducers are able to transform the concentration of the substance under investigation (analyte) in an electrical current. Alternatively, potentiometric transducers are devoted to the determination of a measurable potential or charge accumulation. Finally, impedimetric transducers determine the conductive properties (more precisely, the impedance) of a medium as a function of analyte concentration.

When the electrochemical sensing platform is equipped with at least one biological component, then it is defined an electrochemical biosensor (Pisoschi 2013). The biological component, defined bioelement, leads to a biological event or reaction cascade in the presence of the analyte, which can be followed by the sensor transducer. This component produces a final signal proportional to the concentration of the analyte. Most of the reported biosensors are based on determining a steady state response of the measuring system, where the detector generates the maximum signal. The biological component can be represented by an enzyme, an antibody, a DNA sequence, an aptamer, a recognition protein, a membrane receptor or even intact cells (Sadik et al. 2009).

Many electrochemical biosensors of PAs are simply based on immobilized amino oxidases (AOs), which provide the biocatalytic oxidation of PAs (Fig. 1). The enzymatic reaction generates hydrogen peroxide, which is detected at a working electrode. Some AOs allow the development of versatile electrochemical biosensors and found applications in a variety of food samples.

Bienzyme biosensors are also very popular and involve the biocatalysis of the enzymatic products of AOs by a second enzyme. The working electrode will finally detect the production or the consumption of the redox species produced by the enzymatic activity of the second enzyme. These systems often employ an electrochemical mediator. As an example, horseradish peroxidase (HRP) is often used in combination with AOs in bienzyme electrode configurations (AOs/HRP). The $\mathrm{H}_{2} \mathrm{O}_{2}$ produced by the oxidase in the presence of PAs is subsequently reduced by HRP in the presence of an electrochemical mediator, which is finally reduced at the electrode.

Some electrochemical biosensors for PAs are included in flow injection analysis (FIA) systems. A FIA system is based on the injection of a sample into a liquid flow. The major advantages of these systems are the short contact time of the analyte with the biosensor, the high sample throughput and the small sample volume (Spener et al. 1997).

\section{Biosensors for the determination of polyamines in food}

As above mentioned, the knowledge of PA content in food would be important to modulate the diet regime for a specific human health condition. Nevertheless, to avoid the risk of adverse outcomes (Pegg 2013), the current tendency of the agro-food industry is to launch products
Fig. 1 a Schematic representation of an electrochemical biosensor involving iron oxide nanoparticles; $\mathbf{b}$ the bioelement (bovine serum amine oxidase) immobilized on an iron oxide nanoparticle acting as support and electrochemical transducer. This biosensor was applied for the determination of polyamines in tumor tissues (Bonaiuto et al. 2016)
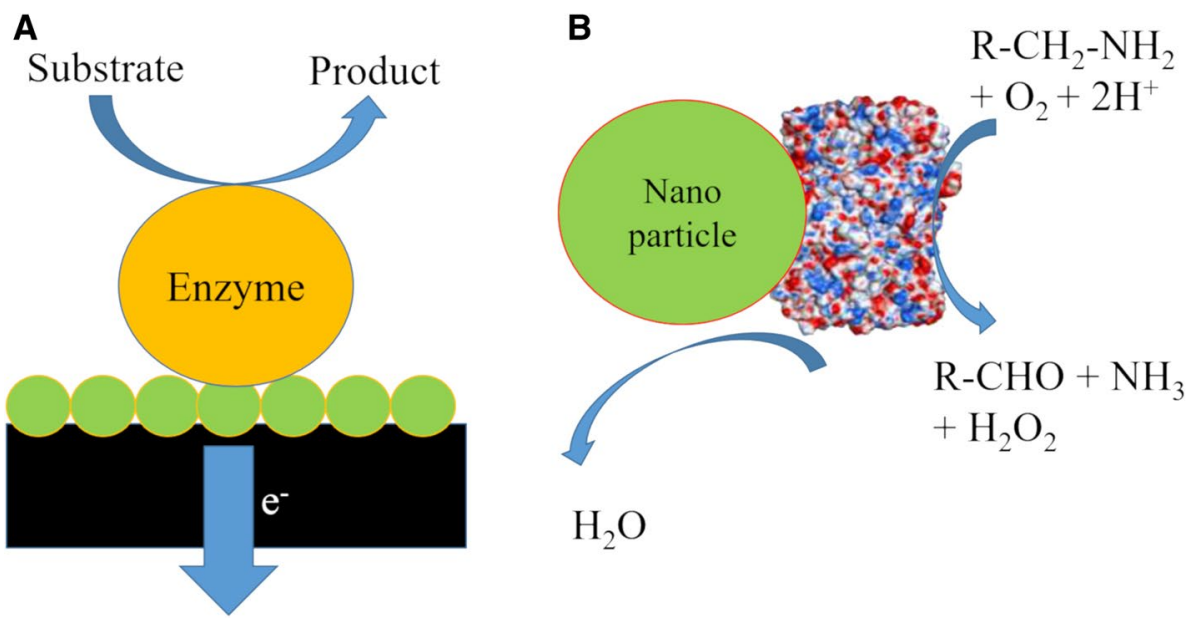

$\mathrm{H}_{2} \mathrm{O}$ 
with low PAs levels on the market (Gardini et al. 2016). For this reason, PAs are largely accepted as markers of food quality (Mohammed et al. 2016) and several original papers dealing with the PA content in food items were published in the past (Ali et al. 2011; Cipolla et al. 2007; Kalac and Krausová 2005; Nishimura et al. 2006). Nevertheless, no upper limit of PA levels in food is in place in legislation (Restuccia et al. 2014). Actually, the amount of PAs in food is highly variable, ranging from nanomoles to micromoles per gram, depending on the nature of the food, on environmental conditions and on the possible presence of microorganisms involved in food spoilage. In fact, PAs can be originated from the activity of foodborne bacterial enzymes catalyzing the decarboxylation of amino acids (Ladero et al. 2010; Wunderlichová et al. 2014). Thus, the production of PAs by foodborne bacteria is carefully considered by the agro-food industry (Nychas et al. 2016).

Many reports dealing with the development of biosensing devices for the determination of polyamines in food samples can be found in literature, and most of them used single enzyme configurations. Diamine oxidase (DAO) was used for detecting PUT and CAD in vegetable, fish and meat samples (Hashimoto et al. 1990; Luk et al. 1980), putrescine oxidase (PUO) for PUT in fish, meat, alcoholic beverages, animal plasma, and human blood (Xu et al. 1997), polyamine oxidase (PAO) for SPD and SPM in fish, vegetables, human urine and blood (Seiler 1995), spermine oxidase (SMO) for SPM and SPD in human blood (Cervelli et al. 2012) and agmatinase (AUH) for AGM in mollusc samples (Romero et al. 2017).

Other electrochemical sensing applications were based on bienzyme biosensors. These biosensor configurations mainly involved horseradish peroxidase in combination with an amine oxidase. As an example, these two enzymes were co-immobilized on the surface of a graphite electrode with an osmium-redox polymer as electrochemical mediator (Bóka et al. 2012a, b).

Mono-enzyme and bienzyme configurations are both attractive options, and they stimulated a comparison study, which applied these two alternative designs keeping constant DAO as bio-recognition element. In the first case, DAO was directly immobilized onto a platinumworking electrode (poised at $+700 \mathrm{mV}$ ). In the second case, the enzyme was combined with horseradish peroxidase onto glass beads into a FIA reactor using a glassy carbon working electrode. Interestingly, both biosensors displayed low detection limits, similar selectivity toward PUT, CAD and SPM and were successfully applied for the detection of PAs in gilthead bream samples (Tombelli and Mascini 1998).

\section{Biosensors for the determination of polyamines in fish}

Environmental conditions and duration of the storage period before processing affect fish freshness, and the rate of raw material spoilage depends on the fish species and on the degree of microbiological contamination (Prester 2011). Fish spoilage is accompanied by protein hydrolyzation into peptides and free amino acids, which are further degraded to thermally stable biogenic amines and, of course, polyamines. Thus, their levels in fish are potential indicators of food spoilage (Bulushi et al. 2009). Among the variety of PAs in fish, only CAD and PUT have been identified as reliable markers of fish safety and quality (Biji et al. 2016; Wu et al. 2016) and were proposed as indicators of fish freshness using different indexes (Visciano et al. 2012) or computational methods (Zare and Ghazali 2017). It worths mentioning that CAD and PUT were suggested to potentiate the toxic activity of histamine by inhibiting the intestinal histamine-metabolizing enzymes, such as diamine oxidase and histamine $N$-methyltransferase (Bulushi et al. 2009).

Early examples of biosensors for fish quality assessment were proposed in the 1980s, but significant developments were reported only in the 1990s (Venugopal 2002), see Table 1.

Male et al. (1996) reported on a biosensor based on diamine oxidase (DAO) purified from porcine kidney and immobilized on a nylon membrane by glutaraldehyde for measuring CAD and PUT in trout fillets during storage. The enzyme membrane was fixed onto a Pt working electrode and the $\mathrm{H}_{2} \mathrm{O}_{2}$ produced by the enzyme catalysis was measured at $+0.4 \mathrm{~V}$ with respect to an $\mathrm{Ag} / \mathrm{AgCl}$ reference electrode. DAO from cicer seedlings was exploited to evaluate the variations of total polyamine content in salted anchovies during the ripening process (Draisci et al. 1998). Several publications based on putrescine oxidase (PUO) as convenient bio-recognition system are available in literature. PUO obtained from Micrococcus rubens was immobilized onto a micro planar electrode for the detection of hydrogen peroxide (Chemnitius et al. 1992) and onto screen-printed Pt electrodes (Chemnitius and Bilitewski 1996) by glutaraldehydealbumin crosslinking. The analytical specificity was studied toward PUT, CAD, SPD and AGM, and both biosensors were successfully applied to evaluate fish freshness along with storage. These electrode configurations were applied for the detection of PAs in pollock, mackerel, and codfish.

PUO (from Micrococcus roseus) was immobilized on controlled pore glass (CPG) beads and placed into a small FIA reactor. The enzymatically produced $\mathrm{H}_{2} \mathrm{O}_{2}$ in the presence of PAs was assessed via electrochemical oxidation at a Pt-working electrode poised at $+600 \mathrm{mV}$ versus $\mathrm{Ag} / \mathrm{AgCl}$. 
Table 1 Biosensors proposed for the determination of polyamines in fish samples

\begin{tabular}{|c|c|c|c|c|c|c|c|}
\hline References & Electrode & Enzyme & Mediator & PAs & Tec. & LOD & Linearity \\
\hline Chemnitius et al. (1992) & $\mathrm{Au}$ & PUO & - & PUT & A & $0.03 \mu \mathrm{M}$ & Up to $3 \mu \mathrm{M}$ \\
\hline Male et al. (1996) & $\mathrm{Pt}$ & DAO & - & $\begin{array}{l}\text { PUT } \\
\text { CAD }\end{array}$ & A & $50 \mu \mathrm{M}$ & Up to $6 \mathrm{mM}$ \\
\hline $\begin{array}{l}\text { Chemnitius and Bilitewski } \\
\text { (1996) }\end{array}$ & $\mathrm{Pt}$ & PUO & - & $\begin{array}{l}\text { PUT } \\
\text { CAD } \\
\text { SPD } \\
\text { AGM }\end{array}$ & A & $\begin{array}{l}0.06 \mu \mathrm{M} \\
0.1 \mu \mathrm{M} \\
0.1 \mu \mathrm{M} \\
1.5 \mu \mathrm{M}\end{array}$ & $\begin{array}{l}\text { Up to } 200 \mu \mathrm{M} \\
\text { Up to } 14 \mu \mathrm{M} \\
\text { Up to } 20 \mu \mathrm{M} \\
\text { Up to } 40 \mu \mathrm{M}\end{array}$ \\
\hline Tombelli and Mascini (1998) & $\mathrm{Pt}$ & $\mathrm{DAO}$ & - & $\begin{array}{l}\text { PUT } \\
\text { CAD }\end{array}$ & A & - & - \\
\hline Draisci et al. (1998) & $\mathrm{Pt}$ & DAO & - & $\begin{array}{l}\text { PUT } \\
\text { CAD } \\
\text { SPD } \\
\text { SPM }\end{array}$ & A & $\begin{array}{l}0.5 \mu \mathrm{M} \\
0.5 \mu \mathrm{M} \\
0.5 \mu \mathrm{M} \\
0.5 \mu \mathrm{M}\end{array}$ & $\begin{array}{l}1 \mu \mathrm{M}-2 \mathrm{mM} \\
1 \mu \mathrm{M}-2 \mathrm{mM} \\
1 \mu \mathrm{M}-1 \mathrm{mM} \\
1-50 \mu \mathrm{M}\end{array}$ \\
\hline Carsol and Mascini (1999) & $\mathrm{Pt}$ & PUO & - & PUT & A & $0.06 \mu \mathrm{M}$ & Up to $400 \mu \mathrm{M}$ \\
\hline Niculescu et al. (2000) & Graphite & $\mathrm{AO} / \mathrm{HRP}$ & $\mathrm{PVI}_{13}$-dmeOs + PEGDGE & PUT & & $0.17 \mu \mathrm{M}$ & $1-400 \mu \mathrm{M}$ \\
\hline Inaba et al. (2004) & Oxygen sensor & AUH & - & AGM & A & $5 \mu \mathrm{M}$ & $10 \mu \mathrm{M}-1 \mathrm{mM}$ \\
\hline Saby et al. (2004) & $\mathrm{GC}$ & PUO/HRP & Ferrocene & PUT & A & $5 \mu \mathrm{M}$ & $5-75 \mu \mathrm{M}$ \\
\hline Mureşan et al. (2008) & GC & PUO/HRP & Os-redox polymer & $\begin{array}{l}\text { PUT } \\
\text { CAD } \\
\text { SPD } \\
\text { AGM }\end{array}$ & A & - & Up to $5 \mathrm{mM}$ \\
\hline Rodríguez-Méndez et al. (2009) & Pt SPE & - & Phthalocyanine & CAD & $\mathrm{CV}, \mathrm{SWV}$ & - & - \\
\hline Alonso-Lomillo et al. (2010) & SPCE & $\begin{array}{l}\text { DAO/HRP } \\
\text { MAO/HRP }\end{array}$ & Ferrocene & $\begin{array}{l}\text { PUT } \\
\text { CAD } \\
\text { SPD } \\
\text { SPM }\end{array}$ & $\mathrm{CA}$ & - & - \\
\hline Kivirand et al. (2011) & Oxygen sensor & DAO & Nylon, dimethyl sulfate & CAD & A & - & $9 \mu \mathrm{M}-1.1 \mathrm{mM}$ \\
\hline Bóka et al. (2012b) & Graphite & PUO/HRP & Os mediator & PUT & A & $5 \mu \mathrm{M}$ & $10-500 \mu \mathrm{M}$ \\
\hline Telsnig et al. (2012) & $\mathrm{CP}$ & $\mathrm{AO}$ & $\mathrm{MnO}_{2}$ & $\begin{array}{l}\text { PUT } \\
\text { CAD }\end{array}$ & DPV & $\begin{array}{l}91 \mu \mathrm{M} \\
98 \mu \mathrm{M}\end{array}$ & $\begin{array}{l}0.27-0.76 \mathrm{mM} \\
0.29-0.86 \mathrm{mM}\end{array}$ \\
\hline Hasanzadeh et al. (2013) & $\mathrm{CP}$ & - & $\mathrm{MCM}-41-\mathrm{Fe}_{2} \mathrm{O}_{3}$ & $\begin{array}{l}\text { PUT } \\
\text { CAD }\end{array}$ & DPV & $\begin{array}{l}60 \mathrm{nM} \\
50 \mathrm{nM}\end{array}$ & $\begin{array}{l}0.9-35 \mu \mathrm{M} \\
0.1-10 \mu \mathrm{M}\end{array}$ \\
\hline Henao-Escobar et al. (2013) & SPCE & MAO & TTF/AuNPs & $\begin{array}{l}\text { PUT } \\
\text { CAD }\end{array}$ & $\mathrm{CA}$ & $\begin{array}{l}9.9 \mu \mathrm{M} \\
19.9 \mu \mathrm{M}\end{array}$ & $\begin{array}{l}9.9-74.1 \mu \mathrm{M} \\
19.6-107.1 \mu \mathrm{M}\end{array}$ \\
\hline Saghatforoush et al. (2014) & GC & - & $\begin{array}{l}\text { B-cyclodextrin/graphene } \\
\text { oxide } / \mathrm{SO}_{3} \mathrm{H}\end{array}$ & CAD & DPV & $20 \mathrm{nM}$ & $50-500 \mathrm{nM}$ \\
\hline Gumpu et al. (2016) & GC & DAO & $\mathrm{CeO}_{2}$ nanoparticles & PUT & A & $10 \mathrm{nM}$ & $0.1 \mu \mathrm{M}-5 \mathrm{mM}$ \\
\hline Henao-Escobar et al. (2016) & SPCE & PUO & Tetrathiafulvalene & PUT & $\mathrm{CA}$ & $10 \mu \mathrm{M}$ & $10-200 \mu \mathrm{M}$ \\
\hline Leonardo and Campàs (2016) & SPCE & DAO & $\mathrm{Co}(\mathrm{II})$-phthalocyanine & $\begin{array}{l}\text { PUT } \\
\text { CAD }\end{array}$ & $\mathrm{CA}$ & $\begin{array}{l}1.03 \mu \mathrm{M} \\
0.60 \mu \mathrm{M}\end{array}$ & - \\
\hline Leonardo and Campàs (2016) & SPCE & DAO & Prussian blue & $\begin{array}{l}\text { PUT } \\
\text { CAD }\end{array}$ & $\mathrm{CA}$ & $\begin{array}{l}0.90 \mu \mathrm{M} \\
0.67 \mu \mathrm{M}\end{array}$ & - \\
\hline Leonardo and Campàs (2016) & SPCE & DAO/HRP & Os mediator & $\begin{array}{l}\text { PUT } \\
\text { CAD }\end{array}$ & $\mathrm{CA}$ & $\begin{array}{l}0.90 \mu \mathrm{M} \\
0.47 \mu \mathrm{M}\end{array}$ & - \\
\hline Chauhan et al. (2017) & $\mathrm{Au}$ & $\mathrm{PAO}$ & Chitosan/zeolites/AuNPs & SPD & $\mathrm{CV}, \mathrm{SWV}$ & $0.1 \mu \mathrm{M}$ & $0.2-200 \mu \mathrm{M}$ \\
\hline
\end{tabular}

$A$ amperometry, $A G M$ agmatine, $A O$ amine oxidase, $A U H$ agmatinase, $A u$ gold electrode, $A u N P s$ gold nanoparticles, $C A$ chronoamperometry, $C A D$ cadaverine, $C P$ carbon paste, $C V$ cyclic voltammetry, $D A O$ diamine oxidase, $D P V$ differential pulse voltammetry, $G C$ glassy carbon electrode, $H R P$ horseradish peroxidase, $M A O$ monoamine oxidase, $P A O$ polyamine oxidase, $P t$ platinum electrode, $P U O$ putrescine oxidase, $P U T$ putrescine, $S P C E$ screen printed carbon electrodes, $S P D$ spermidine, $S P E$ screen printed electrode, $S P M$ spermine, $S W V$ square wave voltammetry, TTF tetrathiafulvalene

The biosensor was applied for the determination of PAs in salmon, tuna and mackerel (Carsol and Mascini 1999). This kind of biosensor design could be easily equipped with different enzymes: DAO from porcine kidney and from lentil were used. Hence, biosensor selectivity can be properly tuned toward different AO substrates. 
Biosensors employing electrochemical mediators were proposed as alternative to the direct $\mathrm{H}_{2} \mathrm{O}_{2}$ detection (see Table 1). Ferrocene was used in bienzyme systems: the concomitant immobilization of PUO and HRP on CPG beads as support was applied for the detection of PAs in fish fillets (trout and sole) (Saby et al. 2004). Furthermore, monoamine oxidase/HRP and diamine oxidase/HRP systems deposited on screen printed carbon electrodes were proposed as disposable chronoamperometric bienzymatic biosensors for the quantification of CAD, PUT SPD and SPM in anchovy samples (Alonso-Lomillo et al. 2010). Alternatively, an osmiumredox polymer was exploited as electrochemical mediator. Mureşan et al. (2008) coupled an amine oxidase from grass pea (Lathyrus sativus) with commercial horseradish peroxidase. The enzymes were co-immobilized on the surface of a graphite electrode and the determination of PUT, CAD, AGM and SPD in codfish muscle was accomplished. A similar bienzyme configuration, coupled to an osmium-redox polymer as electrochemical mediator, was utilized for PUT determination in fish muscle sample (turbot) (Niculescu et al. 2000) and silver carp (Bóka et al. 2012b).

A bienzyme biosensor working in the absence of an electrochemical mediator was proposed for AGM determination as indicator of squid freshness (Inaba et al. 2004). In this case PUO was used in combination with agmatinase (AUH). AGM was converted to PUT by AUH and the as produced PUT was further oxidized by PUO. The amount of AGM was determined by the amount of oxygen consumed by an oxygen sensor.

Kivirand et al. (2011) proposed a simple method for the construction of a biosensor based on the immobilization of an amine oxidase inside a coiling thread-shaped tubing around a cylindrical oxygen sensor. The amount of enzyme and the diffusion characteristics of the system enabled to properly modify the sensitivity of the biosensor as a function of the PA content of the sample. The system was proposed for CAD determination in hake samples.

Monoamine oxidase (MAO) was proposed in a system for the determination of PUT and CAD in fish samples (Wang et al. 2013).

Henao-Escobar et al. (2013) proposed a novel design using screen-printed carbon electrodes (SPCE) connected in an array mode with two working electrodes constituted of a mixture of tetrathiafulvalene (TTF), as electron transfer mediator, and carbon ink. The employment of different amounts of monoamine oxidase (MAO) on these modified TTF/SPCEs and the use of gold nanoparticles (AuNPs) allowed the simultaneous determination of PUT and CAD in octopus samples. The same research group proposed a biosensor based on PAO in a similar electrode design for the determination of PUT in octopus (Henao-Escobar et al. 2016). A carbon paste modified with manganese dioxide was proposed by Telsnig et al. (2012) for the development of a biosensor containing immobilized amine oxidase. The hydrogen peroxide produced by the enzyme, following the oxidation of PUT and CAD in fish sauces, was detected by differential pulse voltammetry.

In recent years, the development of novel nanomaterials offered new possibilities for sensing devices with increased electrochemical performances (Magro et al. 2018; Urbanova et al. 2014).

In the work of Leonardo and Campàs (2016), DAO was immobilized on magnetic beads demonstrating the high storage stability of the conjugate and the possibility of designing different sensor architectures. Gumpu et al. (2016) immobilized DAO on ceria $\left(\mathrm{CeO}_{2}\right)$ nanoparticles to improve the enzyme catalytic efficiency. Due to the large isoelectric point difference between DAO $(\mathrm{pI}=6.0)$ and $\mathrm{CeO}_{2}$ nanoparticles $(\mathrm{pI}=9.2)$, the immobilization efficiency was attributable to the strong electrostatic attraction. The resulting biosensor was successfully applied for the determination of PUT in tiger prawn samples. Chauhan et al. (2017) utilized a polyamine oxidase (PAO), immobilized by glutaraldehyde crosslinking on a hybrid constituted of gold nanoparticles and zeolites nanocrystals, for the determination of SPD levels in carp (Labeo) samples. Saghatforoush et al. (2014) demonstrated the feasibility of an enzymeless sensor based on $\beta$-cyclodextrins and graphene oxide immobilized on a glassy carbon electrode, and successfully applied the sensor for the determination of CAD in fish samples.

Finally, different enzymeless sensors were proposed for the determination of PAs in fish. An enzyme-free sensor was proposed by Hasanzadeh et al. (2013). The system, based on $\mathrm{Fe}_{2} \mathrm{O}_{3}$ nanoparticles incorporated into crystalline cetyltrimethylammonium bromide, exhibited relevant electrocatalytic activity toward the electro-oxidation of some PAs. Another enzymeless PA sensor, based on an array of voltammetric electrodes chemically modified with phthalocyanines, was proposed for the monitoring of fish freshness (Rodríguez-Méndez et al. 2009). Differently from enzyme containing sensors, the system did not require any special condition for preservation. Due to the lack of specificity, two models for the statistical data analysis on a large set of PAs (principal component analysis and partial least square-discriminant analysis, PLS-DA) were proposed to properly evaluate fish spoilage. An interesting system based on chemiresistors was applied for the determination of fish degradation (Chandran et al. 2017). The sensor measured the resistance variation following the direct interaction of an analyte molecule with the sensor surface. On these basis, single wall carbon nanotubes (SWCNTs) immobilized on gold electrodes were covalently modified with different cobalt porphyrins and successfully applied to measure PUT and CAD at sub-ppm concentrations in cod and salmon samples (Liu et al. 2015). 


\section{Biosensors for the determination of polyamines in plant samples}

The most common PAs in plants are represented by PUT, SPD and SPM, all implicated in many biological processes, such as cell division, cell elongation, embryogenesis, root formation, floral and fruit development and ripening, pollen tube growth and senescence, and in the response to biotic and abiotic stresses (Osorio and Fernie 2013; Handa et al. 2018). Different studies demonstrated that PUT, CAD, SPM and SPD are practically ubiquitous in all vegetables and fruits at concentrations around few $\mathrm{mg} / 100 \mathrm{~g}$ fresh weight (Liu et al. 2006; Moret et al. 2005; Torrigiani et al. 2008; Valero et al. 2002).

A peculiar biosensor configuration was developed for monitoring the variation of amine content during sweet cherry and apricot fruit ripening under modified atmosphere (see Table 2). The biosensor scheme consisted in an AO immobilized onto a polymeric membrane as biorecognition element in combination with a Pt electrode for the detection of the enzymatically produced $\mathrm{H}_{2} \mathrm{O}_{2}$. The system was very versatile, both for assessing the total amine content using DAO as bioelement, or alternatively for the specific determination of SPD and SPM using the sensing selectivity of PAO (Esti et al. 1998).

Noteworthy, an electrochemical cell integrated in a chromatographic separation technique (i.e., cationexchange liquid chromatography) was proposed for the measurement of PAs in soybean seeds. The electrochemical sensor, based on square wave voltammetry, led to competitive detection limits in comparison to the other detectors usually coupled to chromatography, without the need of any chemical derivatization (Pineda et al. 2001).

\section{Biosensors for the determination of polyamines in meat}

The concentration of PAs depends on the different type of meat (Kalač 2006) and typical values were recently reviewed by Kalač (2014). In general, a high amount of PUT and other amines have been attributed to microbial growth and, thus, to meat spoilage (Jairath et al. 2015). Inner organs and metabolically active tissues (liver, kidney, spleen, etc.) possess high SPM levels, even if manufacturing practices, packaging techniques, additives and storage conditions may alter the PA content (Ruiz-Capillas and Jiménez-Colmenero 2004).

PUO was immobilized on a platinum electrode by glutaraldehyde chemistry leading to a biosensor for monitoring meat freshness and meat quality via potential-step chronoamperometry (see Table 3). A nafion membrane was applied to the sensing surface to avoid electrode fouling (Yano et al. 1996). Moreover, PUO was linked to chitosan beads via glutaraldehyde and used for the combined detection of PUT, CAD and SPD by amperometry to monitor the incipient spoilage of chicken meat during storage at 5 and $15{ }^{\circ} \mathrm{C}$ (Okuma et al. 2000).

A porous nylon membrane modified with DAO was applied for the determination of the total PA content in dryfermented sausages by measuring consumed oxygen by a platinum electrode (Hernández-Cázares et al. 2011). DAO was immobilized on a screen-printed carbon electrode and included in a FIA assembly to quantify PUT and CAD in chicken meat samples (Telsnig et al. 2013). A bienzyme configuration based on horseradish peroxidase and amine oxidase co-immobilized on the surface of a graphite electrode, with osmium-redox polymer as electrochemical mediator, was applied for the estimation of meat spoilage (Bóka et al. 2012b).

Noteworthy, a considerable number of studies reporting on enzymeless PA electrochemical sensors in meat are available in literature (see Table 3). Among them, sensors based on boron doped diamond electrodes represent an effective
Table 2 Biosensors proposed for the determination of PAs in plant samples

\begin{tabular}{lllllll}
\hline References & Electrode & Enzyme & PAs & Tec. & LOD & Linearity \\
\hline Esti et al. (1998) & \multirow{2}{*}{ Pt } & DAO & PUT & A & $1 \mu \mathrm{M}$ & $2 \mu \mathrm{M}-2 \mathrm{mM}$ \\
& & & SPM & & $1 \mu \mathrm{M}$ & $2-50 \mu \mathrm{M}$ \\
& & & SPD & $1 \mu \mathrm{M}$ & $2-50 \mu \mathrm{M}$ \\
Esti et al. (1998) & Pt & PAO & SPM & A & $1 \mu \mathrm{M}$ & $2 \mu \mathrm{M}-0.7 \mathrm{mM}$ \\
& & & SPD & & $1 \mu \mathrm{M}$ & $2 \mu \mathrm{M}-1 \mathrm{mM}$ \\
Pineda et al. (2001) & $\mathrm{Au}$ & - & PUT & SWV & $0.2 \mu \mathrm{M}$ & - \\
& & & CAD & & $0.19 \mu \mathrm{M}$ & \\
& & & SPM & & $0.11 \mu \mathrm{M}$ & \\
& & & SPD & & $0.8 \mu \mathrm{M}$ & \\
& & & AGM & & $0.06 \mu \mathrm{M}$ & \\
\hline
\end{tabular}

$A$ amperometry, $A O$ amine oxidase, $A u$ gold electrode, $C A D$ cadaverine, $D A O$ diamine oxidase, $P A O$ polyamine oxidase, $P t$ platinum electrode, $P U O$ putrescine oxidase, $P U T$ putrescine, $S P D$ spermidine, $S P M$ spermine, $S W V$ square wave voltammetry 
Table 3 Biosensors proposed for the determination of polyamines in meat samples

\begin{tabular}{|c|c|c|c|c|c|c|c|}
\hline References & Electrode & Enzyme & Mediator & PAs & Tec. & LOD & Linearity \\
\hline Yano et al. (1996) & $\mathrm{Pt}$ & PUO & - & PUT & $\mathrm{CA}$ & - & $5-60 \mu \mathrm{M}$ \\
\hline Okuma et al. (2000) & $\mathrm{Pt}$ & PUO & - & $\begin{array}{l}\text { PUT } \\
\text { CAD } \\
\text { SPD }\end{array}$ & A & $0.01 \mathrm{mM}$ & Up to $1 \mathrm{mM}$ \\
\hline Favaro et al. (2007) & $\mathrm{Au}$ & - & - & $\begin{array}{l}\text { PUT } \\
\text { CAD } \\
\text { SPM } \\
\text { SPD } \\
\text { AGM }\end{array}$ & IPAD & $\begin{array}{l}1-20 \mathrm{mg} / \mathrm{L} \\
0.5-10 \mathrm{mg} / \mathrm{L}\end{array}$ & - \\
\hline Hernández-Cázares et al. (2011) & $\mathrm{Pt}$ & $\mathrm{DAO}$ & - & $\begin{array}{l}\text { PUT } \\
\text { CAD }\end{array}$ & A & - & - \\
\hline Telsnig et al. (2013) & SPCE & $\mathrm{AO}$ & $\mathrm{MnO}_{2}$ & $\begin{array}{l}\text { PUT } \\
\text { CAD }\end{array}$ & A & $0.3 \mu \mathrm{M}$ & $1-50 \mu \mathrm{M}$ \\
\hline Henao-Escobar et al. (2015) & $\begin{array}{l}\text { Boron } \\
\text { doped } \\
\text { diamond }\end{array}$ & - & - & $\begin{array}{l}\text { PUT } \\
\text { CAD }\end{array}$ & SWV & - & $\begin{array}{l}22-65 \mu \mathrm{M} \\
22-65 \mu \mathrm{M}\end{array}$ \\
\hline Lin et al. (2015) & $\mathrm{GC}$ & - & $\begin{array}{l}\text { (Trifluoroacetyl)azobenzene dye } \\
\text { CNT } \\
\text { Nafion }\end{array}$ & $\begin{array}{l}\text { PUT } \\
\text { CAD }\end{array}$ & $\mathrm{CV}$ & - & - \\
\hline Liu et al. (2015) & $\mathrm{Au}$ & - & $\begin{array}{l}\text { SWCNT } \\
\text { Co-porphyrins }\end{array}$ & $\begin{array}{l}\text { PUT } \\
\text { CAD }\end{array}$ & Conductance & $2.5 \mathrm{ppm}$ & - \\
\hline Apetrei and Apetrei (2016) & SPCE & - & Bisphthalocyanine polypyrrole & PUT & $\mathrm{CV}$ & $0.34 \mu \mathrm{M}$ & - \\
\hline
\end{tabular}

$A$ amperometry, $A G M$ agmatine, $A u$ gold electrode, $C A$ chronoamperometry, $C A D$ cadaverine, $C N T$ carbon nanotubes, $C V$ cyclic voltammetry, $D A O$ diamine oxidase, $G C$ glassy carbon electrode, IPAD integrated pulsed amperometric detection, $P t$ platinum electrode, $P U O$ putrescine oxidase, $P U T$ putrescine, SPCE screen printed carbon electrodes, SPD spermidine, SPM spermine, SWCNT single wall carbon nanotubes, $S W V$ square wave voltammetry

sensing platform. The wide available potential window, especially in the anodic region, and the fouling resistance are the main advantages over other materials (Luong et al. 2009). This material was successfully used for the direct measurement of different PAs. For example, Henao-Escobar et al. (2015) measured the content of CAD and PUT in ham samples applying a multivariate calibration method in good agreement with HPLC analyses. A promising alternative to boron doped diamond electrodes is represented by carbon nanotubes. The nanomaterial has stimulated the interest for the fabrication of electrochemical biosensors due to its unique combination of excellent mechanical, chemical and electrical properties (Yang et al. 2013). Lin et al. (2015) developed an electrochemical sensor based on (trifluoroacetyl)azobenzene, which reacts with amine compounds, coupled to carbon nanotubes on a glassy carbon electrode.

The chemiresistor approach, based on cobalt porphyrins-single wall carbon nanotubes (SWCNTs)-gold electrodes already presented in paragraph 3.1, was brilliantly employed for the detection of volatile PUT and CAD at subppm concentrations in chicken and pork meat samples (Liu et al. 2015). Apetrei and Apetrei (2016) applied an array of screen printed carbon electrodes modified with polypyrrole or bisphthalocyanine to monitor beef freshness over 10 days. The detection procedure was essentially based on cyclic voltammetry. The typical voltammetry of polypyrrole and bisphthalocyanine changes in the presence of PUT depending on the interactions between the amine compound and the sensing layer. Finally, Favaro et al. (2007) coupled chromatographic separation with pulsed amperometric detection (IPAD), and were able to detect various PAs in different meat samples, such as fresh meat, ham and fermented sausages.

\section{Biosensors for the determination of polyamines in dairy products}

In general, PA content is lower in milk than in cheese (Ali et al. 2011; Benkerroum 2016) and is related to milk yield, lactation period and type of cow (Kalac and Krausová 2005; Kalač 2014). The PA content in cheeses is affected by various factors (milk protein content, bacteria occurrence, thermal treatment and storage conditions (Samková et al. 2013), and among cheeses, the total PA level is higher in cheeses with long maturation than in fresh ones (Loizzo et al. 2013).

Few papers reported on biosensors for the PA detection in dairy products (see Table 4). DAO from Lens culinaris, immobilized onto a polymeric membrane and coupled to a platinum working electrode, led to good analytical performances in cheeses and was applied for the determination 
Table 4 Sensors proposed for the determination of polyamines in dairy products

\begin{tabular}{|c|c|c|c|c|c|c|c|}
\hline References & Electrode & Enzyme & Mediator & PAs & Tec. & LOD & Linearity \\
\hline Compagnone et al. (2001) & $\mathrm{Pt}$ & DAO & - & $\begin{array}{l}\text { PUT } \\
\text { CAD }\end{array}$ & A & $\begin{array}{l}1 \mu \mathrm{M} \\
1 \mu \mathrm{M}\end{array}$ & $\begin{array}{l}5 \mu \mathrm{M}-2 \mathrm{mM} \\
5 \mu \mathrm{M}-2 \mathrm{mM}\end{array}$ \\
\hline Sun et al. (2003) & $\mathrm{Au}$ & - & - & $\begin{array}{l}\text { PUT } \\
\text { CAD } \\
\text { SPD } \\
\text { SPM }\end{array}$ & PAD & $\begin{array}{l}0.4 \mu \mathrm{M} \\
0.2 \mu \mathrm{M} \\
0.1 \mu \mathrm{M} \\
0.4 \mu \mathrm{M}\end{array}$ & $\begin{array}{l}2 \mu \mathrm{M}-0.5 \mathrm{mM} \\
4 \mu \mathrm{M}-0.5 \mathrm{mM} \\
1 \mu \mathrm{M}-0.2 \mathrm{mM} \\
7 \mu \mathrm{M}-0.4 \mathrm{mM}\end{array}$ \\
\hline Carelli et al. (2007) & $\mathrm{Pt}$ & DAO & $\begin{array}{l}\text { Polypyrrole } \\
\text { Poly- } \beta \text {-naphthol }\end{array}$ & $\begin{array}{l}\text { PUT } \\
\text { CAD }\end{array}$ & A & - & $\begin{array}{l}\text { Up to } 0.25 \mathrm{mM} \\
\text { Up to } 0.5 \mathrm{mM}\end{array}$ \\
\hline
\end{tabular}

$A$ amperometry, $A u$ gold electrode, $C A D$ cadaverine, $D A O$ diamine oxidase, $P A D$ pulsed amperometric detection, $P t$ platinum electrode, $P U T$ putrescine, $S P D$ spermidine, $S P M$ spermine

of total biogenic amines in Parmigiano Reggiano, Grana Padano and Pecorino Romano cheeses (Compagnone et al. 2001). Another example dealt with a FIA amperometric configuration assembled by the combination of a $\mathrm{Pt}$ (or $\mathrm{Au}$ ) working electrode to commercial DAO entrapped via glutaraldehyde onto an electrosynthetized film (Carelli et al. 2007). The system was characterized by remarkable stability, good sensitivity toward PUT and CAD and by the ability of suppressing aspecific electroactive interferences. The antifouling and anti-interferent activity was studied as a function of the number of layers forming the electrosynthetized film.

An enzymeless electrochemical sensor was proposed as well. Sun et al. (2003) coupled capillary electrophoresis with pulsed amperometric detection (PAD) and applied the system for the analysis of PAs in milk. Under optimized conditions, PUT, CAD, SPD, and SPM were well resolved.

\section{Biosensors for the determination of polyamines in alcoholic beverages}

Alcoholic beverages, such as wine and beer, constitute a category of fermented products, which can contain significant amounts of PAs (Wunderlichová et al. 2014). Predominant PAs in wine are PUT and AGM, where they are produced during the spontaneous malolactic fermentation process by decarboxylation of free amino acids. Their final content in wine is related to several factors, such as grape variety, amino acid content, aging and winemaking practices. PAs were also found in beer, even if their concentrations are lower than in wine. The PA content in beer is influenced by the barley variety used in the brewing process, malting technology, wort processing, and the conditions adopted during fermentation (Kalac and Krízek 2003; Romero et al. 2003).

Only few examples of electrochemical sensors were reported in literature (see Table 5). Similarly to the bienzyme sensors above presented, PUO (from Kocuria rosea) was co-immobilized on a graphite electrode with horseradish peroxidase using an osmium complex as electrochemical mediator. The proposed system operated at low applied potential, hence reducing the effects of interfering species, and was successfully applied for the determination of PUT in beer (Bóka et al. 2012a). DAO (from Lathyrus sativus) was immobilized on a gold screen printed electrode and applied for the determination of PUT in wine and beer samples (Fusco et al. 2011). Finally, an enzymeless sensor was proposed by De Borba and Rohrer (2007) by integrating a chromatographic separation with IPAD, and enabling the detection of different PAs in alcoholic beverages.

Table 5 Sensors proposed for the determination of polyamines in alcoholic beverages

\begin{tabular}{|c|c|c|c|c|c|c|c|}
\hline References & Electrode & Enzyme & Mediator & PAs & Tec. & LOD & Linearity \\
\hline De Borba and Rohrer (2007) & $\mathrm{Au}$ & - & - & $\begin{array}{l}\text { PUT } \\
\text { CAD } \\
\text { AGM } \\
\text { SPM } \\
\text { SPD }\end{array}$ & IPAD & $\begin{array}{l}0.44 \mu \mathrm{M} \\
0.67 \mu \mathrm{M} \\
1.38 \mu \mathrm{M} \\
0.18 \mu \mathrm{M} \\
0.44 \mu \mathrm{M}\end{array}$ & $\begin{array}{l}2-113 \mu \mathrm{M} \\
1-49 \mu \mathrm{M} \\
1.5-77 \mu \mathrm{M} \\
0.5-25 \mu \mathrm{M} \\
0.7-34 \mu \mathrm{M}\end{array}$ \\
\hline Fusco et al. (2011) & $\mathrm{Au}-\mathrm{SPE}$ & DAO & - & PUT & CA & $2.3 \mu \mathrm{M}$ & 7.9-226.9 $\mu \mathrm{M}$ \\
\hline Bóka et al. (2012a) & Graphite & PUO/HRP & Os-mediator & $\begin{array}{l}\text { PUT } \\
\text { CAD } \\
\text { SPD }\end{array}$ & A & $5 \mu \mathrm{M}$ & $10-250 \mu \mathrm{M}$ \\
\hline
\end{tabular}

$A$ amperometry, $A G M$ agmatine, $A u$ gold electrode, $C A$ chronoamperometry, $C A D$ cadaverine, $D A O$ diamine oxidase, $H R P$ horseradish peroxidase, IPAD integrated pulsed amperometric detection, $O s$ osmium, $P U O$ putrescine oxidase, $P U T$ putrescine, $S P D$ spermidine, $S P E$ screen printed electrode, SPM spermine 


\section{Biosensors for the determination of endogenous polyamines}

PAs are crucial metabolites for normal cell life and a lot of research work has been carried out to elucidate their role in cell physiology and disease (Handa et al. 2018; Ramani et al. 2014; Igarashi and Kashiwagi 2010; Wortham et al. 2007). Polyamines are implicated in cellular replication and differentiation, metabolism regulation, protein synthesis (Igarashi and Kashiwagi 2015), membranes stabilization (Grancara et al. 2016) and nucleic acid functions (Pasini et al. 2014; Ramani et al. 2014). They also act as secondary messengers and growth factors (Larqué et al. 2007; Moinard et al. 2005), showing important effects on embryonic and fetal development (Hussain et al. 2017). PAs were also reported to act as free radical scavengers, transition metal chelators (Bardócz 1995; Das and Misra 2004; Groppa et al. 2007; Lagishetty and Naik 2008; Lovaas 1996) and enzyme inhibitors (Douki et al. 2000; Lovaas 1996; Tadolini 1988).

\section{Biosensors for the determination polyamines in cancer}

Many papers and reviews reported on the high PA concentration in neoplastic cells with respect to normal cells (MurrayStewart et al. 2016; Park and Igarashi 2013; Wallace and Caslake 2001). Moreover, the addition of PAs to normal tissues can promote the development of cancer cells (Soda 2011). For example, polyamine signaling in multicellular systems is clearly involved in tumorigenesis (Hamon et al. 2016). Regarding PAs as cancer biomarkers, several examples were reported, such as breast cancer (Takayama et al.
2016), lung cancer (Fahrmann et al. 2017; Min et al. 2014), prostate cancer (Tsoi et al. 2016) and head and neck cancer (Sugimoto et al. 2010).

Few papers are available in literature reporting on electrochemical determination of PAs in human tumor tissues. Bovine serum amine oxidase (BSAO) was immobilized on iron oxide nanoparticles, which were previously coated by a chromate ion shell and finally incorporated into a carbon paste electrode for the detection of PAs in crude human liver extracts. Noteworthy, the biosensor was able to discriminate between tumorous and healthy tissues (Bonaiuto et al. 2016).

Some electrochemical sensors for the detection of PAs were tested on animal tumor tissues. PAs in rat brain homogenates were separated by chromatography and detected by a post-column electrochemical reactor using PAO as bioelement (Watanabe et al. 1989). Alternatively, SPM, SPD, PUT and CAD from rat brain homogenates were separated by HPLC and measured by an enzymeless electrochemical sensor (Morier-Teissier et al. 1988). Interestingly, PAs were pre-column derivatized with ortho-phthalaldehyde and detected using a glassy carbon working electrode at an applied potential of $+0.65 \mathrm{~V}$. Rat brain, kidney and liver tissues were analyzed by a similar detection system by Zambonin et al. (1991).

\section{Biosensors for the determination of polyamines in human body fluids}

Many analytical methods for the determination of PAs in human body fluid samples (urine, blood, plasma) have been described in literature (Häkkinen et al. 2013; Suh et al. 1997) and several biosensors were proposed (see Table 6).

Table 6 Biosensors proposed for the determination of polyamines in human body fluid samples

\begin{tabular}{|c|c|c|c|c|c|c|c|}
\hline References & Electrode & Enzyme & Mediator & PAs & Tec. & LOD & Linearity \\
\hline Watanabe et al. (1989) & $\mathrm{Pt}$ & PAO & - & $\begin{array}{l}\text { PUT } \\
\text { SPD } \\
\text { SPM }\end{array}$ & A & $\begin{array}{l}0.3 \mathrm{pM} \\
0.6 \mathrm{pM} \\
4 \mathrm{pM}\end{array}$ & $\begin{array}{l}\text { Up to } 0.3 \mu \mathrm{M} \\
\text { Up to } 0.6 \mu \mathrm{M} \\
\text { Up to } 4 \mu \mathrm{M}\end{array}$ \\
\hline Scarciglia et al. (1998) & $\mathrm{Pt}$ & PAO & - & $\begin{array}{l}\text { SPD } \\
\text { SPM }\end{array}$ & CA & - & $1 \mu \mathrm{M}-0.7 \mathrm{mM}$ \\
\hline Nagy et al. (2002) & $\mathrm{Pt}$ & PUO & - & PUT & CA & $50 \mathrm{nM}$ & Up to $50 \mu \mathrm{M}$ \\
\hline Rochette et al. (2005) & $\mathrm{GC}$ & PUO & $\begin{array}{l}\text { Poly(diallydimethylammonium) } \\
\text { chloride } \\
\text { MWCNT }\end{array}$ & PUT & CA & $5 \mu \mathrm{M}$ & $5-200 \mu \mathrm{M}$ \\
\hline Lin et al. (2011) & $\mathrm{Pt}$ & - & $\mathrm{CuO}, \mathrm{Cu}_{2} \mathrm{O}$ & $\begin{array}{l}\text { PUT } \\
\text { CAD } \\
\text { SPD } \\
\text { SPM }\end{array}$ & $\mathrm{CV}, \mathrm{A}$ & $\begin{array}{l}0.11 \mu \mathrm{M} \\
0.27 \mu \mathrm{M} \\
0.05 \mu \mathrm{M} \\
0.06 \mu \mathrm{M}\end{array}$ & $\begin{array}{l}0.5-20 \mu \mathrm{M} \\
1-30 \mu \mathrm{M} \\
0.2-15 \mu \mathrm{M} \\
0.2-15 \mu \mathrm{M}\end{array}$ \\
\hline Boffi et al. (2015) & Graphite SPE & $\begin{array}{l}\text { PAO } \\
\text { SMO }\end{array}$ & Prussian blue & $\begin{array}{l}\text { SPD } \\
\text { SPM }\end{array}$ & CA & $\begin{array}{l}5 \mu \mathrm{M} \\
1 \mu \mathrm{M}\end{array}$ & $\begin{array}{l}10-400 \mu \mathrm{M} \\
3-300 \mu \mathrm{M}\end{array}$ \\
\hline
\end{tabular}

$A$ amperometry, $C A$ chronoamperometry, $C V$ cyclic voltammetry, $G C$ glassy carbon electrode, $P A O$ polyamine oxidase, $P t$ platinum electrode, $P U O$ putrescine oxidase, $P U T$ putrescine, $S M O$ spermine oxidase, $S P D$ spermidine, $S P E$ screen printed electrode, $S P M$ spermine 
PUO was immobilized on a platinum-working electrode achieving the remarkable detection limit of $50 \mathrm{nM}$ for the amperometric determination of PUT in $\mathrm{pH}$-adjusted whole blood samples. Notably, an electropolymerized poly $(m-$ phenylenediamine) (pPDA) size-exclusion layer was used to protect the working electrode from fouling and to prevent signal generation by common electroactive interferents in blood (Nagy et al. 2002). PUO was also used as bioelement in a mediatorless biosensor successfully exploited for PUT detection in artificial human and mouse plasma. A peculiar feature of the presented configuration was the unusual modification of the electrode surface by a dispersion of multi wall carbon nanotubes (MWCNTs) in poly(diallydimethylammonium) chloride. This technological solution promoted the direct electron transfer between the immobilized enzyme and the electrode, excluding interferent effects (Rochette et al. 2005).

A peculiar bienzyme biosensor was prepared by the coimmobilization of a polyamine oxidase (PAO) from Zea mays and a mouse recombinant spermidine oxidase (SMO) on a screen-printed electrode using Prussian blue as redox mediator. The detection of SPD and SPM in blood samples was carried out by measuring the $\mathrm{H}_{2} \mathrm{O}_{2}$ simultaneously produced by the two enzymes by chronoamperometry at $-100 \mathrm{mV}$ (Boffi et al. 2015).

PAO from maize, was immobilized onto a polymeric support and coupled to an $\mathrm{O}_{2}\left(\right.$ or $\left.\mathrm{H}_{2} \mathrm{O}_{2}\right)$ electrode for the monitoring of $\mathrm{O}_{2}$ consumption (or $\mathrm{H}_{2} \mathrm{O}_{2}$ production) along with the enzymatic reaction (Scarciglia et al. 1998). PAO modified porous glass beads, in combination with a Ptworking electrode, was employed as electrochemical detector and integrated to a HPLC for the determination of PAs in human urine (Watanabe et al. 1989). An enzymeless electrochemical sensor exploiting the chelation properties of PAs toward cupric ions was coupled to a HPLC system and used to detect PAs in clinical urine samples. The sensor response depended on the molecular structure and on the amino group position of PAs coordinating the cupric ions immobilized on a platinum electrode surface (Lin et al. 2011).

PAs (in particular PUT, SPD, SPM and CAD) are normally present in human saliva as a result of amino acid degradation by bacterial enzymes. Their concentrations change during the day or the meal and, especially in the case of CAD and PUT, are usually associated with oral malodor or halitosis (Cooke et al. 2003; Goldberg et al. 1994). DAO from Lathyrus cicera was immobilized on a screen-printed electrode modified with Prussian blue in a portable device. This sensor was able to measure the PA content in saliva from healthy volunteers by chronoamperometry at $-0.05 \mathrm{~V}$ (Piermarini et al. 2010).

High PA content in vaginal fluids can be a useful indicator of two pathologies: bacterial vaginosis (BV) and premature rupture of membranes (PROM). PROM is defined as the spontaneous rupture of membranes occurring prior to the onset of labor in pregnant females (Lyons 2015). Nelson et al. (2015) suggested that PAs are important metabolic markers for facilitating the outgrowth of BV-associated bacteria.

PUO was crosslinked with bovine serum albumin by glutaraldehyde on a Pt electrode included in a FIA system and used for the detection of PAs in vaginal fluids (Xu et al. 1997). The proposed sensor was remarkably stable up to 200 measurements and its reliability was nearly $90 \%$ after 10 days of storage. PUO was also immobilized on aminopropyl-CPG particles by glutaraldehyde coupled to a $\mathrm{Pt}$ electrode and included into a FIA assembly. The enzyme reactor displayed a LOD of $10 \mu \mathrm{M}$ toward PUT (Marzouk et al. 1998).

An alternative approach was focused on the evaluation of AO enzymatic activity (PAO or PUO) as indicator of vaginal disease. An amperometric microchip was fabricated by combining a platinum microdisc working electrode to an $\mathrm{Ag}$ / $\mathrm{AgCl}$ reference electrode. The platinum working electrode was coated with a poly-m-phenylenediamine (PPDA) layer to avoid fouling effects from the samples. PUT was used as externally added substrate to determine the unknown PUO activity. A reagent containing a paper disk (i.e., putrescine adsorbed on a Whatman paper) was placed on the sensing surface. Then, the sample containing PUO at unknown concentration was added and the measurement was performed. Due to the experimental arrangement and the small volumes $(6 \mu \mathrm{L})$, the sample came into chemical contact with the reagent by simple diffusion. This system easily measured the PUO activity down to $0.01 \mathrm{U} \mathrm{mL}^{-1}$. Gyurcsányi et al. (2001) compared the electrochemical performances of four electrodes with different geometries, i.e., two microcells with microelectrode arrays equipped with disk shaped working electrodes, and two screen printed electrodes equipped with semicircle and disk geometries. These electrodes were optimized to measure the activity of PUO from vaginal samples and a LOD of $1 \mathrm{mU} \mathrm{mL}^{-1}$ was obtained. Moreover, to provide size exclusion permselectivity, a thin PPDA film was deposited on the platinum working electrode surfaces for the amperometric $\mathrm{H}_{2} \mathrm{O}_{2}$ detection.

\section{Discussion}

The increasing awareness of the importance of PAs in tissues and in foods forces the research toward the development of novel sensing technologies, coping with the characteristics of the different matrixes. According to the literature collection reported in the present review, the usefulness and versatility of electrochemical sensors is undeniable. However, the complex landscape of applications makes the overall picture very heterogeneous. Indeed, some research 
fields boasted a wide range of solutions, whereas others present only restricted group of applications. As an example, electrochemical biosensors for PAs in fish were frequently reported as PAs are considered valuable indicators of fish freshness (Visciano et al. 2012; Zare and Ghazali 2017). On the contrary, plant based foods and alcoholic beverages can count on a limited number of reports. Nevertheless, we believe that the research on electrochemical sensors for the detection of PAs could find new boosts by the rising interests of food industry and personalized medicine.

Notwithstanding many of the reported sensors are dated, they are still competitive in terms of easiness of construction and limit of detection (LOD). However, they generally operate at considerably high applied potential, which limits the applicability of these configurations in real samples due to the presence of electroactive interferents. Mono-enzyme and bienzyme configurations are both attractive options. Nevertheless, the reliability of these systems can be affected by the loss of enzymatic activity during the immobilization of the bioelement.

The use of novel innovative materials led to the creation of competitive enzymeless sensors for the determination of PAs. Noteworthy, analytical devices based on nanomaterials, such as iron oxides (Hasanzadeh et al. 2013) or boron doped diamond (Luong et al. 2009), display interesting performances in terms of LOD and offer many advantages in terms of fouling resistance. In general, differently from enzyme based sensors, these systems do not require special storage conditions. However, generally they lack of specificity.

The protection of the working electrode from fouling and to prevent signal generation from common electroactive interferents is a general issue. Indeed, fouling resistance represents a crucial feature to cope with complex biological and food matrixes. Several strategies were successfully adopted to avoid this detrimental phenomenon. The ability of suppressing aspecific electroactive interferences was provided by electrosynthesizing anti-fouling layers (Carelli et al. 2007), electropolymerising poly ( $m$-phenylenediamine) (pPDA) (Nagy et al. 2002) or by the unusual dispersion of multi wall carbon nanotubes (MWCNTs) (Rochette et al. 2005).

An important distinction should be applied between immersion probe sensors and flow injection analysis (FIA) systems. The major advantages of the latter are the short contact time of the analyte with the sensing device, the high sample throughput and the small sample volume (Spener et al. 1997).

The reported strategies for the immobilization of the bioelements play a key role for the development of versatile sensing configurations and micro- and nanomaterials are suitable tools for designing different sensor architectures for preserving enzyme activity (Leonardo and Campàs 2016; Gumpu et al. 2016).
Concluding, the next generation electrochemical sensors for PAs should consider all the above mentioned aspects, which should be optimized according to the bioelement(s) characteristics and stability and to the specific matrix.

\section{Concluding remarks}

PAs are good indicators of various pathologies and their intake can influence, positively or negatively, human health. In the present review, an overview on reported electrochemical sensors and biosensors for the determination of polyamines was presented, dedicating a special attention to the potential offered by amine oxidases as versatile biorecognition systems. Moreover, enzyme combination with various nanomaterials was highlighted to explore their synergistic effects on the final analytical performances of the resulting sensors. Mono-enzyme, bienzyme and enzymeless configurations were also taken into account. Nevertheless, in contrast with numerous available reports on electrochemical (bio)sensors for the rapid determination of polyamine content in foods (McGrath et al. 2012) and in biological fluids, there are still few examples of applications on human tissue samples. Even if considerable time and efforts will be required for widening the applicability of biosensors, the growing need for rapid in situ analyses will surely open new frontiers for the electrochemical biosensing of polyamines.

According to authors, the proposed technological solutions are suitable to move electrochemical (bio)sensors from the bench to the market (Luong et al. 2008). Sensors and biosensors for the detection of PA are ready to come out from the laboratory and to pass to commercially available devices for their implementation into the everyday life (Reddy et al. 2016). Indeed, miniaturization, low cost, automated analysis, low reagent consumption, portability, minimal user time or skills, and connectivity represent the main advantages with respect to conventional instrumentation.

Acknowledgements The authors thank 'La Sapienza' University of Rome and Italian MIUR (Ministero dell'Istruzione, dell'Università e della Ricerca). EA thanks Wakunaga Pharmaceutical Co. Ltd. (Japan) for the scholarship given to Yuta Kanamori for supporting his $\mathrm{PhD}$ and the Fondazione 'Enrico ed Enrica Sovena'.

\section{Compliance with ethical standards}

Conflict of interest The authors declare that they have no conflict of interest.

Research involving human participants and/or animals The present review does not contain any studies with human participants or animals performed by any of the authors.

Informed consent For this type of study, informed consent is not required. 


\section{References}

Aflaki F, Ghoulipour V, Saemian N, Shiebani S, Salahinejad M (2017) Chemometrics approaches to monitoring of biogenic amines changes in three fish species. J Aquat Food Prod Technol 26(1):43-53

Agostinelli E (2016) Polyamines and transglutaminases: future perspectives. Amino Acids 48(10):2273-2281

Al-Hadithi NN, Saad B (2011) Determination of underivatized polyamines: a review of analytical methods and applications. Anal Lett 44(13):2245-2264

Ali MA, Poortvliet E, Strömberg R, Yngve A (2011) Polyamines in foods: development of a food database. Food Nutr Res 55:5572

Alonso-Lomillo MA, Domínguez-Renedo O, Matos P, Arcos-Martínez MJ (2010) Disposable biosensors for determination of biogenic amines. Anal Chim Acta 665(1):26-31

Apetrei IM, Apetrei C (2016) Application of voltammetric e-tongue for the detection of ammonia and putrescine in beef products. Sens Actuator B Chem 234:371-379

Bachrach U (2010) The early history of polyamine research. Plant Physiol Biochem 48(7):490-495

Bae D-H, Lane DJR, Jansson PJ, Richardson DR (2018) The old and new biochemistry of polyamines. BBA Gen Subj. https://doi. org/10.1016/j.bbagen.2018.06.004

Bardócz S (1995) Polyamines in food and their consequences for food quality and human health. Trends Food Sci Tech 6(10):341-346

Benkerroum N (2016) Biogenic amines in dairy products: origin incidence and control means. Compr Rev Food Sci F 15(4):801-826

Biji K, Ravishankar C, Venkateswarlu R, Mohan C, Gopal T (2016) Biogenic amines in seafood: a review. J Food Sci Technol 53(5):2210-2218

Boffi A, Favero G, Federico R, Macone A, Antiochia R, Tortolini C, Mazzei F (2015) Amine oxidase-based biosensors for spermine and spermidine determination. Anal Bioanal Chem 407(4):1131-1137

Bóka B, Adányi N, Szamos J, Virág D, Kiss A (2012a) Putrescine biosensor based on putrescine oxidase from Kocuria rosea. Enzyme Microb Technol 51(5):258-262

Bóka B, Adányi N, Virág D, Sebela M, Kiss A (2012b) Spoilage detection with biogenic amine biosensors comparison of different enzyme electrodes. Electroanalysis 24(1):181-186

Bonaiuto E, Magro M, Baratella D, Jakubec P, Sconcerle E, Terzo M, Vianello $\mathrm{F}$ (2016) Ternary hybrid $\gamma$ - $\mathrm{Fe}_{2} \mathrm{O}_{3} / \mathrm{Cr}(\mathrm{VI}) /$ amine oxidase nanostructure for electrochemical sensing: application for polyamine detection in tumor tissue. Chem Eur J 22(20):6846-6852

Borisov SM, Wolfbeis OS (2008) Optical biosensors. Chem Rev 108(2):423-461

Bulushi IA, Poole S, Deeth HC, Dykes GA (2009) Biogenic amines in fish: roles in intoxication spoilage and nitrosamine formation-a review. Crit Rev Food Sci 49(4):369-377

Carelli D, Centonze D, Palermo C, Quinto M, Rotunno T (2007) An interference free amperometric biosensor for the detection of biogenic amines in food products. Biosens Bioelectron 23(5):640-647

Carsol M, Mascini M (1999) Diamine oxidase and putrescine oxidase immobilized reactors in flow injection analysis: a comparison in substrate specificity. Talanta 50(1):141-148

Cervelli M, Amendola R, Polticelli F, Mariottini P (2012) Spermine oxidase: ten years after. Amino Acids 42(2):441-450

Chandran GT, Li X, Ogata A, Penner RM (2017) Electrically transduced sensors based on nanomaterials (2012-2016). Anal Chem 89(1):249-275

Chauhan N, Jain U, Gandotra R, Hooda V (2017) Zeolites-AuNPs assembled interface towards amperometric biosensing of spermidine. Electrochim Acta 230:106-115
Chemnitius GC, Bilitewski U (1996) Development of screen-printed enzyme electrodes for the estimation of fish quality. Sens Actuator B Chem 32(2):107-113

Chemnitius GC, Suzuki M, Isobe K, Kimura J, Karube I, Schmid RD (1992) Thin-film polyamine biosensor: substrate specificity and application to fish freshness determination. Anal Chim Acta 263(1):93-100

Chen H, Huang Y, Hsu H, Lin C, Chen W, Lin C, Tsai Y (2010) Determination of histamine and biogenic amines in fish cubes (Tetrapturus angustirostris) implicated in a food-borne poisoning. Food Control 21(1):13-18

Cipolla B, Guillí F, Moulinoux J (2003) Polyamine-reduced diet in metastatic hormone-refractory prostate cancer (HRPC) patients. Biochem Soc Trans 31(2):384-387

Cipolla BG, Havouis R, Moulinoux JP (2007) Polyamine contents in current foods: a basis for polyamine reduced diet and a study of its long term observance and tolerance in prostate carcinoma patients. Amino Acids 33(2):203-212

Compagnone D, Isoldi G, Moscone D, Palleschi G (2001) Amperometric detection of biogenic amines in cheese using immobilised diamine oxidase. Anal Lett 34(6):841-854

Cooke M, Leeves N, White C (2003) Time profile of putrescine cadaverine indole and skatole in human saliva. Arch Oral Biol 48(4):323-327

Damiani E, Wallace HM (2018) Polyamines and cancer. Methods Mol Biol 1694:469-488

Das KC, Misra HP (2004) Hydroxyl radical scavenging and singlet oxygen quenching properties of polyamines. Mol Cell Biochem 262(1-2):127-133

De Borba BM, Rohrer JS (2007) Determination of biogenic amines in alcoholic beverages by ion chromatography with suppressed conductivity detection and integrated pulsed amperometric detection. J Chromatogr A 1155(1):22-30

Douki T, Bretonniere Y, Cadet J (2000) Protection against radiationinduced degradation of DNA bases by polyamines. Radiat Res 153(1):29-35

Draisci R, Volpe G, Lucentini L, Cecilia A, Federico R, Palleschi $\mathrm{G}$ (1998) Determination of biogenic amines with an electrochemical biosensor and its application to salted anchovies. Food Chem 62(2):225-232

Esti M, Volpe G, Massignan L, Compagnone D, La Notte E, Palleschi G (1998) Determination of amines in fresh and modified atmosphere packaged fruits using electrochemical biosensors. J Agric Food Chem 46(10):4233-4237

Fahrmann JF, Grapov D, Wanichthanarak K, De Felice BC, Salemi MR, Rom WN, Miyamoto S (2017) Integrated metabolomics and proteomics highlight altered nicotinamide and polyamine pathways in lung adenocarcinoma. Carcinogenesis 38(3):271-280

Favaro G, Pastore P, Saccani G, Cavalli S (2007) Determination of biogenic amines in fresh and processed meat by ion chromatography and integrated pulsed amperometric detection on au electrode. Food Chem 105(4):1652-1658

Fusco MD, Federico R, Boffi A, Macone A, Favero G, Mazzei F (2011) Characterization and application of a diamine oxidase from Lathyrus sativus as component of an electrochemical biosensor for the determination of biogenic amines in wine and beer. Anal Bioanal Chem 401(2):707-716

Gardini F, Özogul Y, Suzzi G, Tabanelli G, Özogul F (2016) Technological factors affecting biogenic amine content in foods: a review. Front Microbiol 7:1218

Goldberg S, Kozlovsky A, Gordon D, Gelernter I, Sintov A, Rosenberg M (1994) Cadaverine as a putative component of oral malodor. J Dent Res 73(6): 1168-1172

Grancara S, Ohkubo S, Artico M, Ciccariello M, Manente S, Bragadin M, Agostinelli E (2016) Milestones and recent discoveries on 
cell death mediated by mitochondria and their interactions with biologically active amines. Amino Acids 48(10):2313-2326

Groppa MD, Tomaro ML, Benavides MP (2007) Polyamines and heavy metal stress: the antioxidant behavior of spermine in cadmiumand copper-treated wheat leaves. Biometals 20(2):185-195

Gumpu MB, Nesakumar N, Sethuraman S, Krishnan UM, Rayappan JBB (2016) Determination of putrescine in tiger prawn using an amperometric biosensor based on immobilization of diamine oxidase onto ceria nanospheres. Food Bioprocess Technol 9(4):717-724

Gyurcsányi RE, Cristalli A, Nagy G, Nagy L, Corder C, Pendley BD, Lindner E (2001) Analytical performance characteristics of thin and thick film amperometric microcells. Fresenius J Anal Chem 369(3-4):286-294

Häkkinen MR, Roine A, Auriola S, Tuokko A, Veskimäe E, Keinänen TA, Vepsäläinen J (2013) Analysis of free mono- and diacetylated polyamines from human urine by LC-MS/MS. J Chromatogr B 941:81-89

Hamon L, Savarin P, Pastré D (2016) Polyamine signal through gap junctions: a key regulator of proliferation and gap-junction organization in mammalian tissues? BioEssays 38(6):498-507

Handa AK, Tahira F, Mattoo AK (2018) Polyamines: bio-molecules with diverse functions in plant and human health and disease. Front Chem 6(10):1-18

Hasanzadeh M, Bahrami A, Alizadeh M, Shadjou N (2013) Magnetic nanoparticles loaded on mobile crystalline material-41: preparation characterization and application as a novel material for the construction of an electrochemical nanosensor. RSC Adv 3(46):24237-24246

Hashimoto T, Mitani A, Yamada Y (1990) Diamine oxidase from cultured roots of Hyoscyamus niger: its function in tropane alkaloid biosynthesis. Plant Physiol 93(1):216-221

Henao-Escobar W, Domínguez-Renedo O, Asunción Alonso-Lomillo M, Julia Arcos-Martínez M (2013) Simultaneous determination of cadaverine and putrescine using a disposable monoamine oxidase based biosensor. Talanta 117:405-411

Henao-Escobar W, Domínguez-Renedo O, Alonso-Lomillo MA, Arcos-Martínez MJ (2015) Resolution of quaternary mixtures of cadaverine histamine putrescine and tyramine by the square wave voltammetry and partial least squares method. Talanta 143:97-100

Henao-Escobar W, del Torno-de Román L, Domínguez-Renedo O, Alonso-Lomillo MA, Arcos-Martínez MJ (2016) Dual enzymatic biosensor for simultaneous amperometric determination of histamine and putrescine. Food Chem 190:818-823

Hernández-Cázares AS, Aristoy M, Toldrá F (2011) An enzyme sensor for the determination of total amines in dry-fermented sausages. J Food Eng 106(2):166-169

Herrero A, Sanllorente S, Reguera C, Ortiz MC, Sarabia LA (2016) A new multiresponse optimization approach in combination with a D-optimal experimental design for the determination of biogenic amines in fish by HPLC-FLD. Anal Chim Acta 945:31-38

Hierlemann A, Gutierrez-Osuna R (2008) Higher-order chemical sensing. Chem Rev 108(2):563-613

Hulanicki A, Glab S, Ingman F (1991) Chemical sensors: definitions and classification. Pure Appl Chem 63(9):1247-1250

Hussain T, Tan B, Ren W, Rahu N, Kalhoro DH, Yin Y (2017) Exploring polyamines: functions in embryo/fetal development. Anim Nutr 3(1):7-10

Igarashi K, Kashiwagi K (2010) Modulation of cellular function by polyamines. Int J Biochem Cell Biol 42(1):39-51

Igarashi K, Kashiwagi K (2015) Modulation of protein synthesis by polyamines. IUBMB Life 67(3):160-169

Inaba Y, Tokishita S, Hamada-Sato N, Kobayashi T, Imada C, Yamagata H, Watanabe E (2004) Development of agmatine sensor using the combination of putrescine oxidase and agmatinase for squid freshness. Biosens Bioelectron 20(4):833-840

Jairath G, Singh P, Dabur R, Rani M, Chaudhari M (2015) Biogenic amines in meat and meat products and its public health significance: a review. J Food Sci Technol 52(11):6835-6846

Jeevanandam M, Petersen SR (2001) Clinical role of polyamine analysis: problem and promise. Curr Opin Clin Nutr 4(5):385-390

Joshi MS, Ferguson TB, Johnson FK, Johnson RA, Parthasarathy S, Lancaster JR (2007) Receptor-mediated activation of nitric oxide synthesis by arginine in endothelial cells. Proc Natl Acad Sci USA 104(24):9982-9987

Kaeberlein M (2009) Spermidine surprise for a long life. Nat Cell Biol 11(11):1277-1278

Kalač P (2006) Biologically active polyamines in beef pork and meat products: a review. Meat Sci 73(1):1-11

Kalač $\mathrm{P}$ (2014) Health effects and occurrence of dietary polyamines: a review for the period 2005-mid 2013. Food Chem 161:27-39

Kalač P, Krausová P (2005) A review of dietary polyamines: formation implications for growth and health and occurrence in foods. Food Chem 90(1):219-230

Kalač P, Krízek M (2003) A review of biogenic amines and polyamines in beer. J Inst Brew 109(2):123-128

Kivirand K, Rebane R, Rinken T (2011) A simple biosensor for biogenic diamines, comprising amine oxidase-containing threads and oxygen sensor. Sens Lett 9(5):1794-1800

Kuo PC, Lien CW, Mao JY, Unnikrishnan B, Chang HT, Lin HJ, Huang CC (2018) Detection of urinary spermine by using silver-gold/ silver chloride nanozymes. Anal Chim Acta 1009:89-97

Ladero V, Calles-Enriquez M, Fernandez M, Alvarez MA (2010) Toxicological effects of dietary biogenic amines. Curr Nutr Food Sci 6(2):145-156

Lagishetty CV, Naik SR (2008) Polyamines: potential anti-inflammatory agents and their possible mechanism of action. Indian $\mathrm{J}$ Pharmacol 40(3):121-125

Lapa-Guimarães J, Pickova J (2004) New solvent systems for thin-layer chromatographic determination of nine biogenic amines in fish and squid. J Chromatogr A 1045(1):223-232

Larqué E, Sabater-Molina M, Zamora S (2007) Biological significance of dietary polyamines. Nutrition 23(1):87-95

Latorre-Moratalla ML, Bosch-Fusté J, Lavizzari T, Bover-Cid S, Veciana-Nogués MT, Vidal-Carou MC (2009) Validation of an ultra high pressure liquid chromatographic method for the determination of biologically active amines in food. J Chromatogr A 1216(45):7715-7720

Leonardo S, Campàs M (2016) Electrochemical enzyme sensor arrays for the detection of the biogenic amines histamine putrescine and cadaverine using magnetic beads as immobilization supports. Microchim Acta 183(6):1881-1890

Lin M, Chen C, Chen Z (2011) Development of structure-specific electrochemical sensor and its application for polyamines determination. Electrochim Acta 56(3):1069-1075

Lin J, Kukkola J, Sipola T, Raut D, Samikannu A, Mikkola J, Kordas K (2015) Trifluoroacetylazobenzene for optical and electrochemical detection of amines. J Mater Chem A 3(8):4687-4694

Liu J, Honda C, Moriguchi T (2006) Involvement of polyamine in floral and fruit development. JARQ Jpn Agric Res Q 40(1):51-58

Liu SF, Petty AR, Sazama GT, Swager TM (2015) Single-walled carbon nanotube/metalloporphyrin composites for the chemiresistive detection of amines and meat spoilage. Angew Chem Int Ed 54(22):6554-6557

Loizzo MR, Menichini F, Picci N, Puoci F, Spizzirri UG, Restuccia D (2013) Technological aspects and analytical determination of biogenic amines in cheese. Trends Food Sci Technol 30(1):38-55

Lovaas E (1996) Antioxidative and metal-chelating effects of polyamines. Adv Pharmacol 38:119-149 
Luk GD, Bayless TM, Baylin SB (1980) Diamine oxidase (histaminase): a circulating marker for rat intestinal mucosal maturation and integrity. J Clin Invest 66(1):66-70

Luong JHT, Male KB, Glennon JD (2008) Biosensor technology: technology push versus market pull. Biotechnol Adv 26(5):492-500

Luong JHT, Male KB, Glennon JD (2009) Boron-doped diamond electrode: synthesis characterization functionalization and analytical applications. Analyst 134(10):1965-1979

Lyons P (2015) Premature rupture of membranes. In: Skolnik NS (ed) Obstetrics in family medicine (current clinical practice), 1st edn. Springer, New York, pp 65-70

Magro M, Baratella D, Bonaiuto E, de Almeida Roger J, Vianello F (2018) New perspectives on biomedical applications of iron oxide nanoparticles. Curr Med Chem 25(4):540-555

Male KB, Bouvrette P, Luong JH, Gibbs BF (1996) Amperometric biosensor for total histamine putrescine and cadaverine using diamine oxidase. J Food Sci 61(5):1012-1016

Marzouk SAM, Xu CX, Cosofret BR, Buck RP, Hassan SSM, Neuman MR, Sprinkle RH (1998) Amperometric flow injection determination of putrescine and putrescine oxidase. Anal Chim Acta 363(1):57-65

McGrath TF, Elliott CT, Fodey TL (2012) Biosensors for the analysis of microbiological and chemical contaminants in food. Anal Bioanal Chem 403(1):75-92

Michael AJ (2016) Biosynthesis of polyamines and polyamine-containing molecules. Biochem J 473(15):2315-2329

Miller-Fleming L, Olin-Sandoval V, Campbell K, Ralser M (2015) Remaining mysteries of molecular biology: the role of polyamines in the cell. J Mol Biol 427(21):3389-3406

Min JZ, Matsumoto A, Li G, Jiang Y, Yu H, Todoroki K, Toyo'oka T (2014) A quantitative analysis of the polyamine in lung cancer patient fingernails by LC-ESI-MS/MS. Biomed Chromatogr 28(4):492-499

Mohammed GI, Bashammakh AS, Alsibaai AA, Alwael H, El-Shahawi MS (2016) A critical overview on the chemistry clean-up and recent advances in analysis of biogenic amines in foodstuffs. Trend Anal Chem 78:84-94

Moinard C, Cynober L, de Bandt J (2005) Polyamines: metabolism and implications in human diseases. Clin Nutr 24(2):184-197

Moret S, Smela D, Populin T, Conte LS (2005) A survey on free biogenic amine content of fresh and preserved vegetables. Food Chem 89(3):355-361

Morier-Teissier E, Drieu K, Rips R (1988) Determination of polyamines by pre-column derivatization and electrochemical detection. J Liq Chromatogr 11(8):1627-1650

Morsy MK, Zór K, Kostesha N, Alstrøm TS, Heiskanen A, El-Tanahi H, Emnéus J (2016) Development and validation of a colorimetric sensor array for fish spoilage monitoring. Food Control 60:346-352

Mureşan L, Valera RR, Frébort I, Popescu IC, Csöregi E, Nistor M (2008) Amine oxidase amperometric biosensor coupled to liquid chromatography for biogenic amines determination. Microchim Acta 163(3-4):219-225

Murray-Stewart TR, Woster PM, Casero RA (2016) Targeting polyamine metabolism for cancer therapy and prevention. Biochem J 473(19):2937-2953

Nagy L, Nagy G, Gyurcsányi RE, Neuman MR, Lindner E (2002) Development and study of an amperometric biosensor for the in vitro measurement of low concentration of putrescine in blood. J Biochem Biophys Methods 53(1):165-175

Nelson TM, Borgogna JC, Brotman RM, Ravel J, Walk ST, Yeoman CJ (2015) Vaginal biogenic amines: biomarkers of bacterial vaginosis or precursors to vaginal dysbiosis? Front Physiol 6:253

Niculescu M, Nistor C, Frébort I, Pec P, Mattiasson B, Csöregi E (2000) Redox hydrogel-based amperometric bienzyme electrodes for fish freshness monitoring. Anal Chem 72(7):1591-1597
Nishikawa H, Tabata T, Kitani S (2012) Simple detection method of biogenic amines in decomposed fish by intramolecular excimer fluorescence. Food Nutr Sci 3:1020-1026

Nishimura K, Shiina R, Kashiwagi K, Igarashi K (2006) Decrease in polyamines with aging and their ingestion from food and drink. J Biochem 139(1):81-90

Nychas GE, Panagou EZ, Mohareb F (2016) Novel approaches for food safety management and communication. Curr Opin Food Sci 12:13-20

Okuma H, Okazaki W, Usami R, Horikoshi K (2000) Development of the enzyme reactor system with an amperometric detection and application to estimation of the incipient stage of spoilage of chicken. Anal Chim Acta 411(1):37-43

Osorio S, Fernie AR (2013) Biochemistry of fruit ripening. In: Seymour GB, Poole M, Giovannoni JJ, Tucker GA (eds) The molecular biology and biochemistry of fruit ripening. Blackwell Publishing Ltd, Hoboken, pp 1-19

Parchami R, Kamalabadi M, Alizadeh N (2017) Determination of biogenic amines in canned fish samples using head-space solid phase microextraction based on nanostructured polypyrrole fiber coupled to modified ionization region ion mobility spectrometry. J Chromatogr A 1481:37-43

Park MH, Igarashi K (2013) Polyamines and their metabolites as diagnostic markers of human diseases. Biomol Ther 21(1):1-9

Pasini A, Caldarera C, Giordano E (2014) Chromatin remodeling by polyamines and polyamine analogs. Amino Acids 46(3):595-603

Pegg AE (2013) Toxicity of polyamines and their metabolic products. Chem Res Toxicol 26(12):1782-1800

Piermarini S, Volpe G, Federico R, Moscone D, Palleschi G (2010) Detection of biogenic amines in human saliva using a screenprinted biosensor. Anal Lett 43(7-8):1310-1316

Pineda R, Knapp AD, Hoekstra JC, Johnson DC (2001) Integrated square-wave electrochemical detection of biogenic amines in soybean seeds following their separations by liquid chromatography. Anal Chim Acta 449(1):111-117

Pinto L, Díaz Nieto CH, Zón MA, Fernández H, de Araujo MCU (2016) Handling time misalignment and rank deficiency in liquid chromatography by multivariate curve resolution: quantitation of five biogenic amines in fish. Anal Chim Acta 902:59-69

Pisoschi AM (2013) Biosensors as bio-based materials in chemical analysis: a review. J Biobased Mater Bioenergy 7(1):19-38

Pohanka M (2018) Overview of piezoelectric biosensors, immunosensors and DNA sensors and their applications. Materials 11(3):448

Prester L (2011) Biogenic amines in fish products and shellfish: a review. Food Addit Contam A 28(11):1547-1560

Ramani D, De Bandt JP, Cynober L (2014) Aliphatic polyamines in physiology and diseases. Clin Nutr 33(1):14-22

Ramot Y, Tiede S, Bíró T, Abu Bakar MH, Sugawara K, Philpott MP, Paus R (2011) Spermidine promotes human hair growth and is a novel modulator of human epithelial stem cell functions. PLoS ONE 6(7):e22564

Reddy B, Salm E, Bashir R (2016) Electrical chips for biological pointof-care detection. Annu Rev Biomed Eng 18(1):329-355

Restuccia D, Spizzirri U, Puoci F, Parosi OI, Curcio M, Picci N (2014) Accumulation of biogenic amines in foods: hazard identification and control options. In: Ravishankar V, Jamuna Bai R, Jamuna Bai A (eds) Microbial food safety and preservation techniques. CRC Press Taylor \& Francis Group, Boca Raton, pp 53-74

Rivat C, Richebé P, Laboureyras E, Laulin J, Havouis R, Noble F, Simonnet G (2008) Polyamine deficient diet to relieve pain hypersensitivity. Pain 137(1):125-137

Rochette J-F, Sacher E, Meunier M, Luong JHT (2005) A mediatorless biosensor for putrescine using multiwalled carbon nanotubes. Anal Biochem 336(2):305-311 
Rodríguez-Méndez ML, Gay M, Apetrei C, De Saja JA (2009) Biogenic amines and fish freshness assessment using a multisensor system based on voltammetric electrodes comparison between CPE and screen-printed electrodes. Electrochim Acta 54(27):7033-7041

Romero R, Bagur MG, Sánchez-Viñas M, Gázquez D (2003) The influence of the brewing process on the formation of biogenic amines in beers. Anal Bioanal Chem 376(2):162-167

Romero N, Benítez J, Garcia D, González A, Bennun L, García-Robles MA, Uribe E (2017) Mammalian agmatinases constitute unusual members in the family of $\mathrm{Mn}^{2+}$-dependent ureahydrolases. J Inorg Biochem 166:122-125

Ruiz-Capillas C, Jiménez-Colmenero F (2004) Biogenic amines in meat and meat products. Crit Rev Food Sci 44(7-8):489-499

Saby C, Nguyen T, Luong J (2004) An electrochemical flow analysis system for putrescine using immobilized putrescine oxidase and horseradish peroxidase. Electroanalysis 16(4):260-267

Sadik OA, Aluoch AO, Zhou A (2009) Status of biomolecular recognition using electrochemical techniques. Biosens Bioelectron 24(9):2749-2765

Saghatforoush L, Hasanzadeh M, Shadjou N (2014) B-Cyclodextrin/ graphene oxide grafted sulfonic acid: application for electrooxidation and determination of cadaverine in fish samples. $\mathbf{J}$ Electroanal Chem 714-715:79-84

Samková E, Dadáková E, Pelikánová T (2013) Changes in biogenic amine and polyamine contents in smear-ripened cheeses during storage. Eur Food Res Technol 237(3):309-314

Scarciglia L, Compagnone D, Federici G, Palleschi G (1998) Electrochemical probe for polyamines detection in biological fluids. Analysis 26(5):219-222

Seiler N (1995) Polyamine oxidase properties and functions. In: Yu PM, Tipton KF, Boulton AA (eds) Progress in brain research. Elsevier, Amsterdam, pp 333-344

Seiler N, Delcros JG, Moulinoux JP (1996) Polyamine transport in mammalian cells an update. Int $\mathrm{J}$ Biochem Cell Biol 28(8):843-861

Self RL, Wu W, Marks HS (2011) Simultaneous quantification of eight biogenic amine compounds in tuna by matrix solid-phase dispersion followed by HPLC-orbitrap mass spectrometry. J Agric Food Chem 59(11):5906-5913

Shumilina E, Slizyte R, Mozuraityte R, Dykyy A, Stein TA, Dikiy A (2016) Quality changes of salmon by-products during storage: assessment and quantification by NMR. Food Chem 211:803-811

Soda K (2011) The mechanisms by which polyamines accelerate tumor spread. J Exp Clin Cancer Res 30(1):95

Soda K, Dobashi Y, Kano Y, Tsujinaka S, Konishi F (2009) Polyaminerich food decreases age-associated pathology and mortality in aged mice. Exp Gerontol 44(11):727-732

Spener F, Meusel M, Siegmann-Thoss C (1997) Biosensors based on flow-through systems. In: Scheller FW, Schubert F, Fedrowitz J (eds) Frontiers in biosensoric II\%/practical applications. Birkhäuser Verlag, Basel, pp 27-44

Sugimoto M, Wong DT, Hirayama A, Soga T, Tomita M (2010) Capillary electrophoresis mass spectrometry-based saliva metabolomics identified oral breast and pancreatic cancer-specific profiles. Metabolomics 6(1):78-95

Suh JW, Lee SH, Chung BC, Park J (1997) Urinary polyamine evaluation for effective diagnosis of various cancers. J Chromatogr B 688(2):179-186

Sun X, Yang X, Wang E (2003) Determination of biogenic amines by capillary electrophoresis with pulsed amperometric detection. $\mathbf{J}$ Chromatogr A 1005(1):189-195

Tadolini B (1988) Polyamine inhibition of lipoperoxidation the influence of polyamines on iron oxidation in the presence of compounds mimicking phospholipid polar heads. Biochem J 249(1):33-36

Takayama T, Tsutsui H, Shimizu I, Toyama T, Yoshimoto N, Endo Y, Toyo'oka T (2016) Diagnostic approach to breast cancer patients based on target metabolomics in saliva by liquid chromatography with tandem mass spectrometry. Clin Chim Acta 452:18-26

Telsnig D, Terzic A, Krenn T, Kassarnig V, Kalcher K, Ortner A (2012) Development of a voltammetric amine oxidase-modified biosensor for the determination of biogenic amines in food. Int J Electrochem Sci 7:6893-6903

Telsnig D, Kalcher K, Leitner A, Ortner A (2013) Design of an amperometric biosensor for the determination of biogenic amines using screen printed carbon working electrodes. Electroanalysis 25(1):47-50

Thévenot DR, Toth K, Durst RA, Wilson GS (2001) Electrochemical biosensors: recommended definitions and classification. Biosens Bioelectron 16(1-2):121-131

Tombelli S, Mascini M (1998) Electrochemical biosensors for biogenic amines: a comparison between different approaches. Anal Chim Acta 358(3):277-284

Torrigiani P, Bregoli AM, Ziosi V, Costa G (2008) Molecular and biochemical aspects underlying polyamine modulation of fruit development and ripening. Stewart Postharvest Rev 4(2):1-12

Tsoi T, Chan C, Chan W, Chiu K, Wong W, Ng C, Wong K (2016) Urinary polyamines: a pilot study on their roles as prostate cancer detection biomarkers. PLoS ONE 11(9):e0162217

Urbanova V, Magro M, Gedanken A, Baratella D, Vianello F, Zboril R (2014) Nanocrystalline iron oxides composites and related materials as a platform for electrochemical magnetic and chemical biosensors. Chem Mater 26(23):6653-6673

Valero D, Martínez-Romero D, Serrano M (2002) The role of polyamines in the improvement of the shelf life of fruit. Trends Food Sci Technol 13(6):228-234

Venugopal V (2002) Biosensors in fish production and quality control. Biosens Bioelectron 17(3):147-157

Visciano P, Schirone M, Tofalo R, Suzzi G (2012) Biogenic amines in raw and processed seafood. Front Microbiol 3(188):1-10

Wallace HM, Caslake R (2001) Polyamines and colon cancer. Eur J Gastroenterol Hepatol 13(9):1033-1039

Wang CC, Billett E, Borchert A, Kuhn H, Ufer C (2013) Monoamine oxidases in development. Cell Mol Life Sci 70(4):599-630

Watanabe N, Asano M, Yamamoto K, Nagatsu T, Matsumoto T, Fujita K (1989) High performance liquid chromatography of biological polyamines using immobilized enzyme as post-column reactor followed by electrochemical detection. Biomed Chromatogr 3(5):187-191

Wortham BW, Oliveira MA, Patel CN (2007) Polyamines in bacteria: pleiotropic effects yet specific mechanisms. In: Perry RD, Fetherston JD (eds) The genus Yersinia, advances in experimental medicine and biology, vol 603. Springer, New York, pp 106-115

Wu Y, Chen Y, Li L, Yang X, Yang S, Lin W, Deng J (2016) Study on biogenic amines in various dry salted fish consumed in china. $\mathrm{J}$ Ocean Univ China 15(4):681-689

Wunderlichová L, Buňková L, Koutný M, Jančová P, Buňka F (2014) Formation degradation and detoxification of putrescine by foodborne bacteria: a review. Compr Rev Food Sci Food Saf 13(5):1012-1030

Xu CX, Marzouk SAM, Cosofret VV, Buck RP, Neuman MR, Sprinkle RH (1997) Development of a diamine biosensor. Talanta 44(9):1625-1632

Yakovleva M, Bhand S, Danielsson B (2013) The enzyme thermistora realistic biosensor concept. A critical review. Anal Chim Acta $766: 1-12$ 
Yang X, Feng B, He X, Li F, Ding Y, Fei J (2013) Carbon nanomaterial based electrochemical sensors for biogenic amines. Microchim Acta 180(11):935-956

Yano Y, Yokoyama K, Tamiya E, Karube I (1996) Direct evaluation of meat spoilage and the progress of aging using biosensors. Anal Chim Acta 32(2):269-276

Zambonin PG, Guerrieri A, Rotunno T, Palmisano F (1991) Simultaneous determination of $\gamma$-aminobutyric acid and polyamines by o-phthalaldehyde- $\beta$-mercaptoethanol precolumn derivatization and gradient elution liquid chromatography with electrochemical detection. Anal Chim Acta 251(1):101-107

Zare D, Ghazali HM (2017) Assessing the quality of sardine based on biogenic amines using a fuzzy logic model. Food Chem 221:936-943 